\title{
IMPLEMENTATION OF LEARNING DURING THE COVID-19 IN COLLEGE
}

\author{
Submitted: \\ 4 Juni 2021 \\ Accepted: \\ 8 November 2021 \\ Published: \\ 31 Januari 2022
}

\author{
Frans Aditia Wiguna1, Kharisma Eka Putri ${ }^{* 2}$ \\ frans@unpkediri.ac.id ${ }^{1}$, kharismaputri@unpkediri.ac.id ${ }^{2}$ \\ PGSD, FKIP, UN PGRI Kediri ${ }^{1}$ \\ PGSD, FKIP, UN PGRI Kediri ${ }^{2}$
}

\begin{abstract}
The purpose of this study was to obtain information regarding the implementation of learning during the Covid-19 pandemic period in college. This research activity uses a type of library research which means that in obtaining data in the form of information on relevant matters from various sources such as documents, books, magazines, news, and others. The criteria for selected articles and news are those that discuss the implementation of learning during the Covid-19 pandemic in college. From the 10 sources obtained, then the most relevant were selected so that 7 articles were obtained. The results obtained in this study indicate that the implementation of learning during the Covid-19 pandemic in college can be carried out properly and effectively using online learning. Another finding is that the Covid-19 pandemic is a momentum for lecturers and students to start and familiarize online learning with various learning applications. And there are many online learning applications, but the applications that are widely used are the Google Classroom and Whatsapp applications.
\end{abstract}

Keywords: learning, covid-19 pandemic, college

\section{INTRODUCTION}

Currently, the world has been shocked by the outbreak of the Corona Virus or known as the Coronavirus. Coronavirus itself is a virus that can cause illnesses ranging from mild symptoms to severe symptoms. One type of coronavirus that is known to cause illness that can cause severe symptoms. Coronavirus Diseases 2019 (COVID-19) is a new type of disease that has never been identified in humans. General signs if a person is infected with Covid-19 are acute respiratory disorders such as fever, cough, and shortness of breath with an average incubation period of 5-6 days and a maximum incubation period of 14 days. WHO has declared Covid-19 as a public health emergency that has been troubling the world community since January 30, 2020. According to kompas.com, accessed on May 29, 2021, at $13.00 \mathrm{WIB}$, there were 99.690 active cases of Covid-19 in Indonesia as of May 29, 2021. 
Coronavirus is a large family of viruses that cause mild to severe symptoms to appear. There are at least two types of Coronavirus that are known and cause severe symptoms, they are Middle East Respiratory Syndrome (MERS) and Severe Acute Respiratory Syndrome (SARS). Whereas Coronavirus Diseases 2019 or COVID-19 is a new type of virus that has not been previously identified in humans. Common signs of being infected with the Covid-19 virus are symptoms of acute respiratory distress, namely fever, cough, shortness of breath, with an average incubation period of 5-6 days and a maximum incubation period of 14 days. (Yurianto\& Ahmad, 2020).

The outbreak of the Covid-19 virus in Indonesia has had a significant impact on the entire community and various groups. According to Kompas, 28/03/2020 the impact of the virus was felt in various fields including the economic field, social sector, tourism sector, and even education. The first circular letter issued by the government due to the outbreak of the Corona-19 virus on March 18, 2020, that all indoor and outdoor activities in all sectors be temporarily postponed to reduce the spread of the Corona-19 virus, especially in the education sector. On March 24, 2020, the Minister of Education and Culture of the Republic of Indonesia issued Circular Letter Number 4 of 2020 regarding the Implementation of Education in the Emergency Period for the Spread of Covid-19, in the Circular, it is clarified that learning activities are carried out at home with an online or networked learning system or known as distance learning which is carried out to provide a meaningful distance learning experience for students. Studying at home can be focused on life skills education, one of which is regarding the Covid-19 pandemic.

The implementation of learning in college must also be carried out remotely through good cooperation between lecturers and students as well as supporting facilities and infrastructure. Distance learning is learning that is carried out not face to face or face to face but through cyberspace. With a distance learning system in the online form, students have the opportunity to learn without being limited by space and time. Online learning is according to (Moore, Dickson-Deane \& Galyen, 2011) Online learning is learning that uses the internet network with accessibility, connectivity, flexibility, and the ability to bring up various types of learning interactions. In carrying out online learning, students can interact with lecturers using digital technology of online learning applications such as google classroom, LMS, video conferences such 
as zoom and google meet, telephone, live chat such as Whatsapp group, and many more.

The purpose of this research is to obtain information regarding the implementation of learning during the Covid-19 pandemic in college. How can the implementation of learning during the Covid-19 pandemic in college be carried out properly and effectively?

\section{METHOD}

This study uses library research methods. Library research is research that is done by collecting information and data from various library sources such as documents, books, magazines, historical stories, news, and so on. According to experts, library research is a theoretical study, other scientific references that are closely related to the culture, values, and norms that develop in the social situation being tested (Sugiyono, 2012). This research collects information and data obtained from articles and news in online journals.

Based on the research conducted by the researcher, the researcher got various articles and news. The selected news and articles are related to discussions about the impact of the Covid-19 virus and online learning. From the 10 sources obtained, the most suitable were selected, namely 6 articles. The research technique used is documentation, by looking for data related to things or variables in the form of notes, books, papers or articles, journals, and news. (Arikunto, 2010)

Validity test using triangulation of data sources obtained. The analysis uses 4 stages including 1. Collecting data; 2. Reduce data obtained; 3. Appropriate data display; and 4. Summing up.

\section{RESULTS}

The outbreak of the Covid-19 pandemic, which was previously carried out face-to-face at school, now wants it or not, whether we like it or not, or whether we are ready or not ready to do remote learning at home. Online distance learning can use a wide selection of online learning application facilities that use digital technology such as google classroom, LMS, video conferences such as zoom and google meet, telephone, live chat such as Whatsapp group, and many more. Learning activities are carried out by delivering material through video conferences so that lecturers can monitor participation in online distance learning and assign assignments to 
determine the extent to which students understand distance learning or lectures through the online system.

The implementation of distance learning in college during the Covid-19 pandemic showed various results including according to (Sadikin \& Hamidah, 2020) the results of their research stated that online learning was effective in overcoming learning that allowed lecturers and students to communicate or interact in the virtual classroom so that lecture activities can be accessed anywhere and anytime. Online learning makes students learn more independently and can increase student motivation in learning. However, there are advantages and disadvantages of online learning where student lecture activities are not monitored optimally by lecturers during the process of online learning activities. On the other hand, the weakness of online learning is related to internet signals and the high cost of internet quota is a separate obstacle in carrying out online learning activities. Another advantage of online learning during the Covid-19 pandemic is that it can suppress the spread of Covid-19 in college.

On the other hand (Dewantara \& Nurgiansah, 2021) stated that if online learning was continuously carried out for PGRI Yogyakarta University students, it would be ineffective, due to the emergence of boredom because activities seemed to be carried out repeatedly so that they reached a saturation point. Less than half of the material that students can absorb, another problem is the ability to use internet facilities for lecturers and students are still relatively low. So that online learning will be effective when it is done at any time but not continuously for a full semester. In this study, it was emphasized that in the future online learning should only be carried out during certain conditions that make it impossible to carry out face-to-face learning activities, for example when a natural disaster occurs and along with the increasing professionalism of the teaching staff in the use of various online applications so that learning is not so boring.

Meanwhile, according to (Fitriyani, Fauzi \& Sari, 2020) from the results of data analysis carried out in their research, it can be concluded that from 8 indicators of learning motivation, namely concentration, curiosity, spiritedness, independence, readiness, enthusiasm, or encouragement, never give up, and confident the result is that the average percentage score is $80.27 \%$ with very good criteria, from these results it can be said that during the Covid-19 pandemic that hit almost all of part in the earth, this is not a reason for students to stay motivated to learn even the motivation is still high, although in practice there are still deficiencies found, there is no other choice except to maximize online lecture activities because this is an emergency like now, only technology connected in transferring knowledge from lecturers to students. 
According to (Yudiawan, 2020) in his research online learning in Islamic Universities since the outbreak has been implemented and is going well. The policies that have been taken to manage college during the Covid-19 period in implementing online learning are considered appropriate, according to the needs in the current situation and conditions. Meanwhile, in terms of input, in terms of the quality of lecturers and students, they are quite competent when preparing and conducting online learning. The substance of the material delivered is the same when compared to face-to-face classes at school. However, problems arise from the nontechnical side. Where the problem is related to the network and the cost of data packets is something that students and lecturers need to pay attention to. Especially for those who live in areas that still lack signals, such as the West Papua region with diverse demographics and people whose economy is affected by the Covid-19 pandemic. Technical steps should be taken to overcome problems related to the network and academic costs of each student. Online learning products during Covid-19 to improve understanding of technology for students. This is a momentum with the Covid-19 pandemic for students in the 3T region, it has become and has implemented information technology as a matter of course.

According to (Ningsih, 2020) in her research based on questionnaires that were distributed to students of the Educational Technology Study Program at Baturaja University, $100 \%$ of the students of the Educational Technology Study Program conducted online learning activities in the even semesters of 2019/2020 academic year. However, 93.5\% prefer face-to-face learning to online learning. Due to the limitations of students to provide internet quota for a long period, the understanding of the material is minimal and direct interaction is very limited. Although students prefer face-to-face learning, several online media are very popular with students when online learning activities are carried out, namely data 1). Google Classroom (46.8\%), 2). Whatsapp (27.4\%), 3). Edmodo (19, 4\%) and 4). Zoom (6.4\%). The results of this study can be used as a basis for the use of online media, especially in the Education Technology Study Program.

According to (Fuadi, Musriandi \& Suryani, 2020) in their research, the impact of Covid-19 cannot be avoided, especially in the use of several online learning applications by teaching staff in this case are lecturers in carrying out lecture activities. Not only students, but lecturers also strive to provide the best, interesting, and effective learning activities for students to fulfill their obligations as educators. There are many types of applications that are often used by lecturers at college to conduct online lecture 
activities including; 1). zoom, 2). Google classroom, 3). Whatapp groups, 4). google meet, 5). Skype, 6). Webex, 7). e-mail, 8). Edmodo and 9). CamStudio.

While according to (Rosali, 2020) based on the results of his research, it can be concluded that the learning or lectures carried out during the Covid-19 pandemic were in the Geography education department as a whole has used an online learning model by using several applications such as 1). V-class, 2). meet Unsil, 3). zoom, 4). Whatsapp, 5). telegrams, 6). Google classroom, 7). youtube, 8). Facebook, and 9). messenger. Every lecturer on average uses two applications in one lecture activity, such as Google Classroom and WhatsApp because they are more practical and require less quota than other applications. Online lecture activities run well and smoothly, but most of the lecturers and students feel that the implementation of lectures is not as ideal as face-toface learning as before. Communication activities that are intertwined are not smooth so that the material is difficult to understand, especially for subjects that need to do the practicum. The results of student lecture activities using online learning are varied, from unsatisfactory, moderate to good. Obstacles faced by students and lecturers for online lectures include the availability of internet quotas, unstable networks, and other supporting tools (devices and laptops). Online lectures were considered by some informants to be effective when carried out during the Covid-19 pandemic, this was due to restrictions on health protocols. However, a varied online lecture model is needed for alternatives to be used in the future so that lecture activities remain interesting and in the end, the learning objectives can generally be achieved.

\section{DISCUSSION}

From the 10 articles obtained with the keyword Learning during the Covid-19 in university, obtained 7 articles relevant to the title of this article. From 7 articles that are relevant to the title of the article, there are 3 articles that state that online learning is very effective as a solution to keep learning during the restrictions to minimize the spread of Covid-19. An article explains that online learning in the Covid-19 era is a momentum for lecturers and students to get to know and even get used to using technology in distance learning. And 3 articles describe the use of online learning applications that are often used, including 1). Google Classroom, 2). Whatsapp, 3). Edmodo 
and 4). Zoom. And the most effective is Google Classroom and Whatsapp application because it is the simplest and does not require a lot of internet quota.

The outbreak of the Covid-19 pandemic, which was previously carried out face-to-face at school, now wants it or not, whether we like it or not, or whether we are ready or not ready to do remote learning at home. Online distance learning can use a wide selection of online learning application facilities that use digital technology such as google classroom, LMS, video conferences such as zoom and google meet, telephone, live chat such as Whatsapp group, and many more. Learning activities are carried out by delivering material through video conferences so that lecturers can monitor participation in online distance learning and assign assignments to determine the extent to which students understand online distance learning or lectures. Online learning here is of course based on information and communication technology (ICT) with the main media being an internet connection. Siahaan (2003) explains that electronic learning (online instruction, e-learning, or web-based learning) has three main functions: (1) optional supplements, (2) complements, and (3) substitutions on learning in the classroom (classroom instruction).

Comerchero (2006) states that e-learning is an educational tool that includes communication, efficiency, technology, and self-motivation and further explains that E-learning is efficient because it eliminates distance and round-trip flow. However, E-learning cannot be fully used to replace classroom learning, so many colleges are competing to present the best quality online learning that integrates conventional learning processes and distance learning which results in a combination of various learning models known as the blended learning method. Singh (2003) also stated, "The blended learning mixing or combining web-bases technology to accomplish an educational goal, combining pedagogical approaches (eg behaviorism, cognitivism, constructivism), combining any form of instructional technology with face-to-face instructor-led training". Therefore, the developed e-learning must be comprehensive, capable of accommodating learning that regulates lecturers' roles, students' roles, learning management, utilization of learning resources, to an integrated learning evaluation and monitoring system, namely the Learning Management System (LMS).

Learning Management System (LMS) according to Amiroh (2013) is "A software application used by educators, both schools and colleges as an online learning medium based on the internet (e-learning). In line with this, Riad and EL-Ghareeb (2008) stated "Learning Management System (LMS) is a real software unit integrated with various features for course delivery and management". Related to this Directorate General of Higher Education, Ministry of Education, Culture, Research, and Technology (dikti.Kemendikbud.go.id, July 2021) has even issued an announcement to higher education leaders regarding the 
clustering of college to report activities in the field of online learning by integrating the Learning Management System (LMS) PT with SPADA Indonesia in its assessment.

\section{CONCLUSION}

The results obtained in this study indicate that the implementation of learning during the Covid-19 pandemic in college can still be carried out properly and effectively using online learning. Another finding is that the Covid-19 pandemic is a momentum for lecturers and students to start developing creativity and innovation in familiarizing online learning with various learning applications so that the needs of students and lecturers in learning can be accommodated properly and responsibly. Furthermore, it is also indicated by the Ministry of Education and Culture, Research and Technology are using a learning activity reporting system can be monitored using the Learning Management System (LMS) of PT.

\section{REFERENCES}

Amiroh. (2012) Under E-Learning, Edmodo, Moodle and Schoology. (Online: Sumber http://amiroh.web.id). Diakses 17 September 2021

Arikunto, S. (2010). Prosedur Penelitian Suatu Pendekatan Praktik. Rineka Cipta.

Comerchero, Matthew. (2006). E-Learning Concepts and Technique. USA. Institute for Interactive Technologies. Bloomsburg: University of Pennsylvania.

Dewantara, J. A., \& Nurgiansah, T. H. (2021). Efektivitas Pembelajaran Daring di Masa Pandemi COVID 19 Bagi Mahasiswa Universitas PGRI Yogyakarta. Jurnal Basicedu, 5(1), 367-375.

Dewi, W. A. F. (2020). Dampak Covid-19 terhadap implementasi pembelajaran daring di Sekolah Dasar. Edukatif: Jurnal Ilmu Pendidikan, 2(1), 55-61.

Kemendikbud Riset dan Teknologi. (2021). Pengumuman dalam bidang pembelajaran dan kemahasiswaan (Online: http://dikti.kemdikbud.go.id/pengumuman/ klasterisasi-perguruan-tinggi-di-lingkungan-kementerian-pendidikankebudayaan-riset-dan-teknologi-pada-tahun-2021/). Diakses 19 September 2021

Fitriyani, Y., Fauzi, I., \& Sari, M. Z. (2020). Motivasi belajar mahasiswa pada pembelajaran daring selama pandemik covid-19. Jurnal Kependidikan: Jurnal 
Hasil Penelitian dan Kajian Kepustakaan di Bidang Pendidikan, Pengajaran dan Pembelajaran, 6(2), 165-175.

Fuadi, T. M., Musriandi, R., \& Suryani, L. (2020). COVID-19: PENERAPAN PEMBELAJARAN DARING DI PERGURUAN TINGGI. Jurnal Dedikasi Pendidikan, 4(2), 193-200.

Kompas. (2021). Update 29 Mei; Ada 99.690 Kasus Aktif Covid-19 di Indonesia. Berita Online. $\quad$ https://www.kompas.com/tag/pasien-covid-19? sort=desc\&page=2 diakses 29 Mei 2021. Pukul 13.00 WIB.

Menteri Pendidikan. (2020). Surat Edaran Nomor 3 Tahun 2020 Tentang Pelaksanaan Pendidikan dalam Masa Darurat CoronaVirus (COVID-19).

Moore, J. L., Dickson-Deane, C., \& Galyen, K. (2011). E-Learning, online learning, and distance learning environments: Are they the same? Internet and Higher Education. https://doi.org/10.1016/jiheduc.2010.10.001.

Ningsih, S. (2020). Persepsi Mahasiswa Terhadap Pembelajaran Daring Pada Masa Pandemi Covid-19. JINOTEP (Jurnal Inovasi Dan Teknologi Pembelajaran): Kajian Dan Riset Dalam Teknologi Pembelajaran, 7(2), 124-132.

Riad, Alaa el-din Mohamed dan Haitham El-Ghareeb. (2009). Evaluation of Utilizing Service Oriented Architecture As A Suitable Solution To Align University Management Information System And Learning Management Systems. Turkish Online Journal of Distance Education, Vol. 10 (1). 4.

Rosali, E. S. (2020). Aktifitas Pembelajaran Daring Pada Masa Pandemi Covid-19 Di Jurusan Pendidikan Geografi Universitas Siliwangi Tasikmalaya. GEOSEE, 1(1).

Siahaan, S. (2003). E-Learning (Pembelajaran Elektronik) sebagai salah satu alternatif kegiatan pembelajaran. Jurnal Pendidikan dan Kebudayaan No. 042 Tahun ke-9. Mei 2003.

Singh, H. (2003). Building Effective Blended Learning Programs. Educational Technology, 43, 51-54

Sugiyono. (2012). Metode Penelitian Kuantitatif Kualitatif dan R\&D. Alfabeta.

Sadikin, A., \& Hamidah, A. (2020). Pembelajaran Daring di Tengah Wabah Covid19:(Online Learning in the Middle of the Covid-19 Pandemic). Biodik, 6(2), 214-224. 
Yudiawan, A. (2020). Belajar Bersama COVID 19: Evaluasi Pembelajaran Daring Era Pandemi di Perguruan Tinggi Keagamaan Islam Negeri, Papua Barat. AL-FIKR: Jurnal Pendidikan Islam, 6(1), 10-16.

Yurianto, Ahmad, Bambang Wibowo, K. P. (2020). PEDOMAN PENCEGAHAN DAN PENGENDALIAN CORONAVIRUS DISEASE (COVID-19) (M. I. Listiana Azizah, Adistikah Aqmarina (ed.)) 